\title{
PERSEPSI PETERNAK DAN POLA PEMASARAN SAPI POTONG
}

\section{FARMER PERCEPTION AND MARKETING PATTERN OF THE BEEF CATTLE}

\author{
MS. Fuad ${ }^{1}$, S. Masitoh ${ }^{1 \mathrm{a}}$ dan W. Nahraeni ${ }^{1}$ \\ ${ }^{1}$ Program Studi Agribisnis, Fakultas Pertanian, Universitas Djuanda Bogor \\ Jalan Tol Ciawi 1, Kotak Pos 35 Bogor 16720 \\ a Korespondensi: Siti Masithoh Telp: 0817404973; E-mail: sitimasitoh@unida.ac.id
}

\begin{abstract}
This study aims to determine the characteristics of breeders, the breeder's perception of SPR and marketing pattern of beef cattle in Kecamatan Ciracap. Data was collected through simple random sampling to know the characteristic and perception of breeders. Meanwhile, finding out the marketing agency was carried out by using snowball sampling. Farmer's perception of SPR was measured in Likert Scale through 30 indicators. The result of the reserach indicates that perception of breeder to SPR program in Kecamatan Ciracap is classified into good category, with perceptual value reaching 194,57. The marketing pattern formed involves marketing institution of Ciracap middleman, Tasikmalaya middlemen, TPH Surade, and TPH Tegal Buleud. The sale of beef cattle by the breeders is executed by giving information to the middlemen about the cattle that will be sold.
\end{abstract}

Keywords: Perception, Marketing Pattern, SPR, Beef Cattle

\begin{abstract}
ABSTRAK
Penelitian ini bertujuan untuk mengetahui karakteristik peternak, persepsi peternak terhadap SPR dan pola pemasaran sapi potong di Kecamatan Ciracap. Data dikumpulkan melalui simple random sampling untuk mengetahui karakteristik dan persepsi peternak, sedangkan untuk menelusuri lembaga pemasaran menggunakan snowball sampling. Persepsi peternak terhadap SPR diukur dalam Skala Likert melalui 30 indikator. Persepsi peternak dikatakan tidak baik apabila mempunyai nilai 50 - 117, persepsi kurang baik apabila mempunyai nilai 118 - 185, dan persepsi peternak dikatakan baik jika mempunyai nilai $186-250$. Hasil penelitian menunjukkan bahwa persepsi peternak terhadap program SPR di Kecamatan Ciracap adalah kategori baik, dengan nilai persepsi mencapai 194,57. Pola pemasaran yang terbentuk melibatkan lembaga pemasaran tengkulak Ciracap, tengkulak Tasikmalaya, TPH Surade, dan TPH Tegal Buleud. Penjualan sapi potong oleh peternak dengan cara menyebarkan informasi kepada tengkulak mengenai sapi yang akan di jual.
\end{abstract}

Kata kunci : Persepsi Peternak, SPR, Pola Pemasaran, Sapi Potong 


\section{PENDAHULUAN}

Pemerintah telah melakukan berbagai upaya untuk pengembangan sapi potong. Kebijakan pemerintah didasarkan pada Undang - Undang No.18 Tahun 2009, yang menyatakan bahwa pemerintah berkewajiban untuk melakukan pengembangan usaha pembibitan dengan melibatkan peran serta masyarakat untuk menjamin ketersediaan benih, bibit dan bakalan. Berdasarkan kebijakan tersebut, beberapa program ada yang berkelanjutan dan ada juga program yang tidak berkelanjutan. Program yang telah dilaksanakan diantaranya adalah PSDS (Program Swasembada Daging Sapi), Kawasan Pembibitan Sapi Potong Rakyat, GOOS (Gerakan Optimalisasi Sejuta Sapi), KUPS (Kredit Usaha Pembibitan Sapi), Pembibitan Ternak Unggul, dan Sentra Peternakan Rakyat (SPR).

Salah satu program yang sedang digulirkan oleh pemerintah untuk meningkatkan produksi daging sapi pada tahun 2016 adalah SPR sapi potong Kabupaten Sukabumi yang dilaksanakan di Kecamatan Ciracap. Sentra Peternakan Rakyat merupakan program baru yang melibatkan masyarakat peternak secara langsung untuk berperan aktif dalam menjalankan program tersebut, serta memanfaatkan sumber daya lokal sebagai sumber pakan yang potensial. Program SPR menyatukan peternak sapi potong di Kecamatan Ciracap agar mempunyai kandang dalam pemeliharaan sapi, mengontrol asupan nutrisi pakan, mengontrol gejala penyakit, memberikan asuransi kepada sapi produktif, serta memberikan pinjaman modal bagi peternak aktif. Penjualan sapi potong oleh peternak sebagian besar berdasarkan kondisional keuangan dan kebutuhan peternak. Sistem penjualan sapi seperti ini relatif merugikan peternak karena lemahnya posisi tawar peternak. Pemasaran memegang peranan penting dalam suatu usaha bisnis khususnya di dalam kegiatan usaha peternakan sapi potong di Kecamatan Ciracap.

Pada awal tahun 2016 di Kecamatan Ciracap dilakukan sosialisasi akan adanya program baru dari pemerintah mengenai pemeliharaan sapi potong, yaitu program Sentra Peternakan Rakyat (SPR). Program SPR akan dijalankan oleh peternak sapi potong yang ada di Kecamatan Ciracap, dengan menerapkan prinsip dasar program SPR. Program SPR tersebut perlu mendapatkan tanggapan yang positif dari peternak sapi potong di Kecamatan Ciracap, agar program tersebut dapat berjalan dengan baik dan sesuai dengan yang diharapkan. Sebelum terlaksananya program SPR, sebahagian besar peternak melakukan pemeliharaan sapi dengan cara dilepas di padang pengembalaan atau diabur.

Program SPR mengupayakan agar sistem pemeliharaan sapi potong dikandangkan dengan manajemen dan pemberian pakan yang baik. Hal tersebut memberikan persepsi tersendiri bagi peternak yang akan menjalankan program SPR secara langsung. Oleh karena itu penting untuk dilakukan penelitian mengenai persepsi peternak dan pola pemasaran sapi potong di Kecamatan Ciracap Kabupaten Sukabumi. Tujuan penelitian ini adalah untuk mengetahui karakteristik peternak, persepsi peternak, dan pola pemasaran sapi potong yang saat ini berlaku di Kecamatan Ciracap.

\section{BAHAN DAN METODE}

\section{Kerangka Pemikiran Teoritis Konsep Persepsi}

Menurut Rahmad (2004), ada 2 hal yang bepengaruh terhadap karakteristik manusia yaitu yang berasal dari personal dan situasional. Karakteristik personal adalah faktor faktor yang melekat pada diri individu, dan karakteristik situasional sebagai 
faktor - faktor sosial yang timbul dari luar individu sangat berpengaruh pada prilaku seseorang. Karakteristik menurut Newcomb (1978), meliputi : umur, jenis kelamin, tingkat pendidikan, status sosial ekonomi, bangsa, agama, dan lain - lain. Makin muda umur petani rasa semangat ingin tahu makin besar terhadap hal - hal yang baru (Soekartawi, 1988). Tingkat pendidikan yang lebih baik dan berpengetahuan teknis yang lebih banyak, akan lebih mudah dan mampu berkomunikasi dengan baik (Azhari, 1988). Pendidikan merupakan suatu proses pembentukan watak seseorang sehingga memperoleh pengetahuan, pemahaman dan cara bertingkah laku. Proses pembentukan watak terjadi karena adanya interaksi antara potensi yang dimiliki seseorang (intelegensi, bakat), lingkungan, dan pendidikan (Holle, 2000). Pengalaman beternak akan menjadi dasar dalam pembentukan persepsi individu. Menurut Kasup (1998), mengemukakan bahwa pengalaman akan menjadi dasar tentang pembentukan persepsi individu untuk memberikan tanggapan atau penghayatan.

Reksowardoyo (1983) menyatakan bahwa faktor utama dalam persepsi adalah kemampuan seseorang mengambil sejumlah fakta dan informasi yang terbatas dan kemudian menyesuaikan kepada suatu gambaran secara keseluruhan. Persepsi merupakan suatu proses yang didahului oleh pengindraan. Pengindraan adalah merupakan suatu proses diterimanya stimulus oleh individu melalui alat penerima yaitu alat indra. Pada umunya stimulus tersebut diteruskan oleh syaraf ke otak melalui pusat susunan saraf dan proses selanjutnya merupakan proses persepsi.

\section{Konsep Pola Pemasaran}

Saluran pemasaran sangat penting dalam kegiatan pemasaran sapi potong dari peternak hingga ke konsumen akhir.
Setiap lembaga atau perorangan yang terlibat dalam saluran pemasaran sapi potong harus saling bekerjasama dan tidak ada pihak yang merasa dirugikan. Menurut Hidayat 1998, saluran pemasaran terdiri dari seperangkat lembaga yang melakukan semua kegiatan pemasaran atau fungsi yang digunakan untuk menyalurkan produk barang / jasa dan status kepemilikannya dari produsen ke konsumen.

Antara satu saluran pemasaran dengan saluran pemasaran yang lainnya mempunyai peranannya masing - masing dan saling mempengaruhi. Menurut Limbong dan Sitorus (1985), keputusan saluran pemasaran merupakan salah satu keputusan paling rumit dan menantang yang dihadapi produsen. Artinya, saluran pemasaran yang dipilih akan sangat mempengaruhi semua keputusan pemasaran lainnya.

Lembaga - lembaga pemasaran yang terlibat di dalam proses penyaluran barang dari produsen ke konsumen, dapat dikelompokkan menjadi empat kelompok yaitu : (a) penggolongan menurut fungsi yang dilakukan, (b) penggolongan menurut penguasaan terhadap barang, (c) penggolongan menurut kedudukan dalam struktur pasar, dan (d) penggolongan menurut bentuk usahanya (Limbong dan Sitorus, 1985).

\section{Konsep Marjin Pemasaran}

Panjang pendeknya sebuah saluran pemasaran dapat mempengaruhi margin pemasaran. Semakin panjang saluran pemasaran maka semakin besar pula margin pemasarannya, sebab lembaga pemasaran yang terlibat semakin banyak. Besarnya angka margin pemasaran dapat menyebabkan bagian harga yang diterima oleh petani produsen semakin kecil dibandingkan dengan harga yang dibayarkan konsumen langsung petani, sehingga saluran pemasaran yang terjadi 
semakin panjang dapat dikatakan tidak efisien (Istiyanti, 2010).

Margin pemasaran didefinisikan sebagai perbedaan harga atau selisih harga yang dibayar konsumen dengan harga yang diterima petani produsen. Hal tersebut dapat juga dinyatakan sebagai nilai dari jasa pelaksanaan kegiatan pemasaran sejak dari tingkat produsen sampai ke titik konsumen akhir. Kegiatan untuk memindahkan barang dari titik produsen ke titik konsumen membutuhkan pengeluaran baik fisik maupun materi. Pengeluaran yang harus dilakukan untuk menyalurkan komoditi dari produsen ke konsumen disebut biaya tataniaga. Margin tataniaga terdiri atas biaya - biaya pemasaran dan keuntungan pemasaran (Gonarsyah, 1996/1997).

Tomek dan Robinson, 1990, menyatakan bahwa margin pemasaran dapat berubah karena perubahan dalam faktor harga, efisiensi dari jasa pemasaran, kualitas dan kuantitas jasa pemasaran yang dipergunakan dalam proses produksi produk akhir. Dahl and Hammond, 1997, menyatakan bahwa nilai dari marketing margin adalah selisih harga di tingkat konsumen dan petani dikalikan dengan jumlah produk yang dipasarkan. Secara matematik sederhana the value of the marketing margin $(\mathrm{VMM})=(\mathrm{Pr}-\mathrm{Pf}) \mathrm{Q}$. Konsep primary dan derived demand and supply dapat dilihat pada Gambar 1.

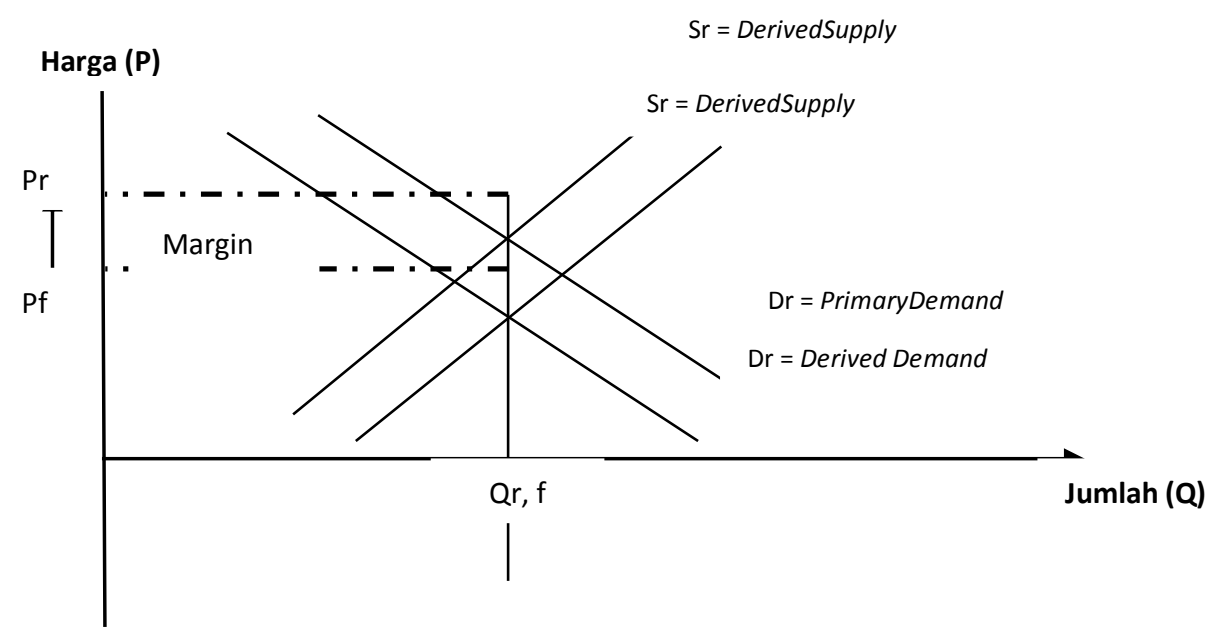

Gambar 1. Marketing Margin (Sumber: Tomek and Robinson, 1990)

Pemasaran memiliki fungsi yang sangat penting dalam menghubungkan produsen dengan konsumen dan memberikan nilai tambah yang besar. Ada sembilan macam fungsi pemasaran yaitu: perencanaan, pembelian, penjualan, transportasi, penyimpanan, standarisasi dan pengelompokan, pembiayaan, komunikasi, dan pengurangan resiko (risk bearing). Tataniaga dalam perusahaan sama pentingnya dengan kegiatan produksi sebab tanpa adanya bantuan sistem tataniaga, petani akan merugi akibat barang - barang hasil produksinya tidak dapat dijual. Sistem distribusi pangan dari produsen ke konsumen dapat terdiri atas beberapa rantai tataniaga (marketing channels) dimana masing masing pelaku pasar memberikan jasa yang berbeda. Besar keuntungan setiap pelaku tergantung pada struktur pasar disetiap tingkatan, posisi tawar, dan efisiensi usaha masing - masing pelaku (Pearce dan Robinson, 2011).

Perbedaan fungsi yang dilakukan setiap lembaga tataniaga menyebabkan perbedaan harga jual dari lembaga yang satu dengan lembaga yang lain sampai 
konsumen akhir. Efesiensi tata niaga terjadi apabila berada dalam mekanisme pasar yang bersaing sempurna dengan besarnya margin tataniaga konstan. Indikator lain yang digunakan untuk mengukur efisiensi tataniaga adalah bagian yang diterima oleh peternak (farmershare). Terdapat dua ukuran efisiensi tataniaga, yaitu : efisiensi operasional dan efisiensi harga.

Efisiensi pemasaran akan terjadi jika : 1) biaya pemasaran dapat ditekan sehingga keuntungan pemasaran dapat lebih tinggi, 2) persentasi perbedaan harga yang dibayarkan konsumen dan produsen tidak terlalu tinggi, 3) tersedianya fasilitas fisik pemasaran, dan 4) adanya kompetisi pasar yang sehat. Umumnya di negara-negara berkembang, empat kriteria di atas tersebut umumnya digunakan sebagai indikator efisiensi pemasaran (Soekartiwi, 1986).

\section{Sentra Peternakan Rakyat (SPR)}

Kebutuhan daging yang belum terpenuhi secara kemandirian pangan nasional, menjadi prioritas pemerintah agar segera keluar dari permasalahan tersebut. Berbagai upaya saat ini sedang dilakukan oleh pemerintah yang bersinergi bersama rakyat, dengan cara melibatkan peternak dan memanfaatkan potensi sumber daya alam yang tersedia. Program Sentra Peternakan Rakyat (SPR) yang diluncurkan pemerintah, merupakan sebuah langkah nyata dalam memberikan gerakan percepatan pembangunan di bidang peternakan. Melalui penerapan strategi yang baik diharapkan menjadikan berdaulatnya peternak Indonesia. Program SPR harus didukung dan dijalankan secara baik oleh masyarakat, dengan harapan Indonesia akan mampu menjadi lumbung ternak terbesar di dunia.

Kementrian

Pertanian menerapkan program SPR untuk menghitung volume sapi lokal yang ada di masyarakat, dengan cara melakukan konsolidasi diantara para peternak sapi rakyat. Target utamanya adalah pada masing - masing SPR terdapat 1.000 ekor populasi indukan. Pada tahun 2016 melalui fasilitas APBN, APBD dan sumber pembiayaan lainnya, pembiayaan terpadu SPR memfungsikan kegiatan lintas sektor yang diarahkan pada lokasi SPR yang sudah ada peternaknya namun kurang berkembang, sehingga perlu untuk diberikan penguatan melalui fasilitas dan prasarana. Strategi SPR yang harus dijalankan meliputi : pengorganisasian, pemuliaan, produktivitas, kesehatan hewan, pakan, pengelolaan hasil ternak, bisnis kolektif, pemberdayaan, reorganisasi dan pelayanan, sehingga strategi tersebut akan menghasilkan satu visi nasional yaitu peternak yang berdaulat.

\section{Lokasi dan Pengumpulan Data}

Penelitian ini dilaksanakan di Kecamatan Ciracap, Kabupaten Sukabumi, Jawa Barat. Pemilihan lokasi penelitian dilakukan secara sengaja (purposive) dengan pertimbangan bahwa Kecamatan Ciracap adalah salah satu wilayah yang menjadi Sentra Peternakan Rakyat (SPR) di Jawa Barat.

Pengambilan data dilakukan mulai dari tanggal 10 Oktober sampai dengan 7 November 2016. Pengumpulan data dilakukan dengan cara pengamatan secara langsung dan wawancara kepada peternak sapi potong. Sampel dalam penelitian ini adalah peternak sapi potong di Kecamatan Ciracap, yang terlibat secara langsung untuk menjalankan program Sentra Peternakan Rakyat (SPR) sapi potong dan individu atau lembaga pemasaran yang berperan dalam pemasaran sapi potong.

Populasi peternak di Kecamatan Ciracap berjumlah 634 peternak, dengan menggunakan Rumus Slovin diambil sebanyak 50 sampel. Pengambilan 
sample peternak dilakukan secara simple random sampling untuk mengetahui persepsi. Responden untuk lembaga pemasaran menggunakan metode snowball sampling, yaitu dengan cara menelusuri lembaga pemasaran lainnya berdasarkan informasi yang diberikan oleh responden awal.

\section{Metode Analisis}

Metode analisis data dilakukan secara kualitatif maupun kuantitatif. Persepsi peternak terhadap SPR menggunakan analisis non parametrik dijelaskan secara deskriptif. Analisis margin tataniaga sapi potong menggunakan metode analisis data kuantitatif. Data yang dikumpulkan antara lain : pengetahuan dalam beternak sapi, tanggapan peternak terhadap SPR, kondisi umum keluarga peternak, lembaga pemasaran sapi potong dan margin tataniaga sapi potong

Persepsi peternak diukur dalam Skala Likert dengan kategori : tujuan pengembangan SPR sebanyak lima indikator, kategori prinsip pengembangan SPR sebanyak sembilan indikator, kategori pelaksanaan SPR sebanyak sembilan indikator, dan kategori program SPR sebanyak tujuh indikator. Persepsi peternak terhadap SPR diukur dengan memberikan sebanyak 30 indikator.

Skala Likert menggunakan lima kategori utama dalam memberikan pilihan kepada peternak dalam menjawab pertanyaan pertanyaan, yaitu :

1. Sangat setuju (strongly agree) $=5$

2. Setuju (agree) $=4$

3. Kurang setuju $=3$

4. Tidak setuju (disagree) $=2$

5. Sangat tidak setuju $=1$

\section{Analisis Margin Pemasaran}

Analisis margin pemasaran bertujuan untuk mengetahui tingkat efisiensi dalam tataniaga sapi potong. Margin pemasaran merupakan perbedaan atau selisih harga di tingkat produsen dengan harga pada konsumen akhir yang mempunyai nilai kegunaan atau penambahan harga pada setiap lembaga pemasaran yang terkait. Analisis margin pemasaran digunakan untuk mengetahui distribusi margin pemasaran yang terdiri atas biaya dari setiap aktifitas pemasaran dan keuntungan dari setiap lembaga pemasaran, serta untuk mengetahui bagian harga yang diterima peternak. Menurut (Limbong dan Sitorus, 1987) rumus yang digunakan dalam menganalisis margin pemasaran adalah :

$$
\begin{aligned}
& \mathrm{MP}=\mathrm{Pr}-\mathrm{Pf} \\
& \mathrm{Sbi}=\frac{\mathrm{Bi}}{\mathrm{Pr}-\mathrm{Pf}} \times 100 \% \\
& \mathrm{Ski}=\frac{\mathrm{ki}}{\mathrm{Pr}-\mathrm{Pf}} \times 100 \%
\end{aligned}
$$

Keterangan rumus :

$$
\begin{aligned}
& \text { MP = Margin Pemasaran } \\
& \text { Pr = Harga tingkat tengkulak } \\
& \text { (Rp/ekor) } \\
& \text { Pf = Harga tingkat petani (Rp/ekor) } \\
& \text { Sbi = Share (bagian) biaya yang } \\
& \text { ke-i }(\%) \\
& \text { Ski = Share (bagian) keuntungan } \\
& \text { yang diperoleh lembaga } \\
& \text { pemasaran ke-i (\%) }
\end{aligned}
$$

\section{HASIL DAN PEMBAHASAN}

\section{Karakteristik Peternak}

\section{Karakteristik}

peternak

berdasarkan jumlah sampel sebanyak 50 peternak yang diteliti meliputi jenis kelamin, umur, tingkat pendidikan, pengalaman beternak, jumlah tanggungan keluarga, dan mata pencaharian. Peternak sapi potong yang menjadi objek penelitian di Kecamatan Ciracap terdiri 
dari $100 \%$ laki - laki, mayoritas umur peternak adalah adalah 40 - 49 tahun yang mencapai $40 \%$, hal ini dikarenakan tidak banyak anak muda yang berminat untuk memelihara sapi potong.

Tingkat pendidikan peternak di Kecamatan Ciracap masih tergolong rendah, dengan ditemukannya sebanyak $58 \%$ peternak adalah lulusan SD sedangkan belum ditemukannya peternak yang lulusan perguruan tinggi. Seiring dengan peluang usaha sapi potong yang semakin menjanjikan, banyak ditemukan peternak pemula yang baru memulai usaha sapi potong. Jumlah tanggungan keluarga peternak mayoritas adalah berjumlah $3-5$ orang, dengan menjadikan usaha ternak sapi potong sebagai usaha sampingan.

\section{Persepsi Peternak Terhadap SPR}

Persepsi peternak terhadap SPR di Kecamatan Ciracap dengan memberikan 30 indikator yaitu : 5 indikator tentang tujuan pengembangan SPR, 9 indikator tentang prinsip pengembangan SPR, 9 indikator tentang pelaksanaan SPR, dan 7 indikator tentang program SPR. Persepsi peternak terhadap tujuan pengembangan SPR adalah mengenai usaha peternakan rakyat dalam suatu perusahaan kolektif yang dikelola dalam satu manajemen.
Persepsi peternak terhadap prinsip pengembangan SPR adalah mengenai pembentukan organisasi SPR untuk mewujudkan usaha peternakan yang berorientasi bisnis dan berbadan hukum. Persepsi peternak terhadap pelaksanaan SPR adalah mengenai sosialisasi yang dilakukan oleh pemerintah daerah bersama perguruan tinggi yang telah menjajaki kerjasama untuk mengawal dan mendampingi SPR. Persepsi peternak terhadap program SPR adalah tentang program SPR yang mampu mengubah pola pikir peternak menjadi lebih baik.

Persepsi peternak sapi potong terhadap program SPR yang dilaksanakan di Kecamatan Ciracap dibedakan menjadi 3 kategori. Persepsi yang dimiliki peternak yaitu persepsi tidak baik (skor 50 - 117), kurang baik (skor 118 - 185) dan baik (skor 186- 250). Berdasarkan hasil penelitian, persepsi peternak terhadap SPR di Kecamatan Ciracap mempunyai nilai rata-rata 194,57. Artinya persepsi peternak terhadap SPR di Kecamatan Ciracap adalah kategori baik. Mayoritas peternak sapi potong menyambut positif dan bersedia menjalankan program SPR sesuai dengan prinsip dan pedoman yang telah disepakati bersama (Tabel 1).

Tabel 1 Pengelompokan Persepsi Peternak terhadap SPR Berdasarkan Skor

\begin{tabular}{cccccc}
\hline $\begin{array}{c}\text { NO } \\
\text { INDIKATOR }\end{array}$ & $\begin{array}{c}\text { TOTAL } \\
\text { SKOR }\end{array}$ & $\begin{array}{c}\text { NO } \\
\text { INDIKATOR }\end{array}$ & $\begin{array}{c}\text { TOTAL } \\
\text { SKOR }\end{array}$ & $\begin{array}{c}\text { NO } \\
\text { INDIKATOR }\end{array}$ & $\begin{array}{c}\text { TOTAL } \\
\text { SKOR }\end{array}$ \\
\hline 1 & 209 & 11 & 163 & 21 & 186 \\
2 & 204 & 12 & 195 & 22 & 170 \\
3 & 200 & 13 & 194 & 23 & 197 \\
4 & 202 & 14 & 167 & 24 & 193 \\
5 & 199 & 15 & 220 & 25 & 186 \\
6 & 194 & 16 & 172 & 26 & 219 \\
7 & 196 & 17 & 171 & 27 & 230 \\
8 & 209 & 18 & 187 & 28 & 224 \\
9 & 208 & 19 & 160 & 29 & 202 \\
10 & 188 & 20 & 216 & 30 & 176 \\
\hline & & \multicolumn{4}{c}{ Rata - Rata } \\
\hline
\end{tabular}




\section{Pola Pemasaran Sapi Potong di Kecamatan Ciracas}

Pemeliharaan sapi potong di Kecamatan Ciracap bukanlah menjadi prioritas utama oleh masyarakat, namun menjadi usaha sampingan setelah bertani atau nelayan. Peternak melakukan pemeliharaan sapi potong sebagai usaha sampingan dengan alasan mayoritas adalah dijadikan sebagai tabungan, jika suatu saat terdesak memerlukan uang maka penjualan sapi dapat dijadikan alternatif untuk memperoleh uang. Jika mendapatkan uang lebih dari hasil bertani atau nelayan, maka mereka akan membeli sapi baru untuk dipelihara lagi.

Pada saat peternak ingin menjual sapi karena terdesak membutuhkan uang, maka peternak tersebut akan menghubungi beberapa orang tengkulak yang ada di desa atau kecamatan. Patokan harga jual ditentukan oleh peternak, kemudian tengkulak akan melakukan penawaran dengan harga yang lebih rendah. Penjualan sapi oleh peternak kepada tengkulak bukan berdasarkan berat bobot sapi per kg, namun harga jual sapi berdasarkan kesepakatan secara visual dengan mempertimbangkan bentuk fisik sapi tersebut.

Hal seperti ini bisa saja merugikan salah satu pihak, namun sudah menjadi hal yang biasa karena penjualan dan kesepakatan harga sudah berdasarkan kesepakatan bersama. Peranan tengkulak mengenai hal tersebut biasanya lebih mendominasi, karena berpengalaman dalam membeli sapi dan posisi peternak yang berada pada saat membutuhkan uang untuk suatu keperluan.

Saluran tataniaga merupakan serangkaian organisasi yang menghubungkan antara peternak sebagai produsen sapi potong dengan konsumen sebagai penerima produk akhir yang terdiri dari berbagai lembaga perantara. Penyampaian produk sapi potong hingga konsumen akhir memerlukan suatu mata rantai pemasaran.

Berdasarkan hasil wawancara dengan peternak sampel, hampir semua peternak menjual ternaknya melalui tengkulak atau broker antar desa di Kecamatan Ciracap. Tengkulak merupakan pedagang yang berperan dalam membeli dan mengumpulkan sapi yang dijual oleh peternak, kemudian menjualnya kembali untuk mendapatkan keuntungan. Peternak belum mampu memasarkan sapi potong tanpa melalui perantara tengkulak. Saluran tataniaga sapi potong di Kecamatan Ciracap terdapat 2 saluran utama yaitu :

1. Peternak -- Tengkulak Desa -Tengkulak Besar -- RPH -- Pasar -Konsumen.

2. Peternak -- Tengkulak Besar -RPH - Pasar -- Konsumen.

Saluran satu dan dua mempunyai sedikit perbedaan dalam pemasaran. Perbedaan tersebut terdapat pada saluran satu yang melewati lembaga pemasaran tengkulak desa, sedangkan hal tersebut tidak terdapat pada saluran dua. Pada saluran satu terdapat 4 lembaga perantara, dan pada saluran dua terdapat 3 lembaga perantara. Hubungan antar lembaga lembaga tersebut akan membentuk pola pola pemasaran yang khusus. Pola pemasaran yang terbentuk dari peternak ke konsumen akhir disebut sistem pemasaran.

Lembaga pemasaran adalah badan usaha atau individu yang menyelenggarakan pemasaran, menyalurkan jasa dan komoditi dari produsen ke konsumen akhir, serta mempunyai hubungan dengan badan usaha atau individu lainnya. Fungsi pemasaran merupakan kegiatan - kegiatan atau tindakan - tindakan yang dapat memperlancar proses penyampaian barang atau jasa (Limbong dan Sitorus, 1987). Sistem tataniaga mempunyai 
lembaga tataniaga yang berperan penting dalam memperlancar fungsi - fungsi tataniaga yaitu fungsi pertukaran, fungsi fisik dan fungsi fasilitas. Secara khusus belum ada lembaga resmi di Kecamatan Ciracap yang menangani masalah pemasaran sapi. Pemasaran sapi masih didominasi oleh tengkulak tingkat desa yang bersedia membeli sapi bagi peternak yang menjual sapinya.

Lembaga yang terlibat dalam pemasaran sapi potong di Kecamatan Ciracap pada umumnya adalah tengkulak desa, tengkulak besar, RPH Sukabumi, dan Pasar Sukabumi. Lembaga pemasaran dapat memperlancar pergerakan barang dari produsen hingga konsumen melalui berbagai kegiatan. Lembaga pemasaran tersebut membeli sapi dari peternak kemudian menyalurkannya hingga ke konsumen akhir.

Peternak biasanya akan menjual sapi ke tengkulak desa pada saat memerlukan uang untuk suatu keperluan, pada saat itu juga tengkulak akan sedikit menekan harga lebih rendah dari penawaran peternak. Pada awalnya harga jual ditentukan oleh peternak, kemudian terjadi tawar menawar harga yang lebih didominasi oleh tengkulak hingga pada akhirnya sapi berhasil terjual walaupun terkadang harga jual tidak memuaskan peternak. Rasa tidak puas oleh peternak muncul ketika harga jual lebih didominasi oleh tengkulak, sedangkan peternak membutuhkan uang untuk suatu keperluan. Berdasarkan data pada Tabel 22, sebanyak 11 orang (22 \%) belum pernah menjual sapi karena baru memulai memelihara sapi, namun mayoritas peternak $(76 \%)$ mengaku tidak puas terhadap harga jual sapi yang belum sesuai dengan keinginan peternak. Rasa ketidakpuasan peternak terhadap harga jual sapi kepada tengkulak, juga disebabkan oleh belum tersedianya lembaga resmi di Kecamatan Ciracap yang mengatur tentang penjualan sapi.

Fungsi pemasaran yang terjadi pada setiap lembaga pemasaran yang terlibat dalam pemasaran sapi potong di Kecamatan Ciracap akan berbeda. Masing -masing lembaga pemasaran mempunyai rutinitas kegiatan yang tidak sama karena disesuaikan dengan kebutuhan setiap lembaga. Lembaga dan fungsi pemasaran sapi potong di Kecamatan Ciracap dapat dilihat pada Tabel 2.

Tabel 2 Lembaga dan Fungsi Pemasaran Sapi Potong di Kecamatan Ciracap

\begin{tabular}{|c|c|c|c|c|c|c|}
\hline \multicolumn{2}{|r|}{ Fungsi Pemasaran } & \multirow[t]{2}{*}{ Peternak } & \multirow[t]{2}{*}{$\begin{array}{c}\text { Tengkulak } \\
\text { Desa }\end{array}$} & \multirow[t]{2}{*}{$\begin{array}{c}\text { Tengkulak } \\
\text { Besar }\end{array}$} & \multirow[t]{2}{*}{$\begin{array}{c}\text { RPH } \\
\text { Sukabumi } \\
\end{array}$} & \multirow[t]{2}{*}{$\begin{array}{c}\text { Pasar } \\
\text { Sukabumi }\end{array}$} \\
\hline 1 & $\begin{array}{l}\text { Fungsi } \\
\text { Pertukaran }\end{array}$ & & & & & \\
\hline & Pembelian & $\mathrm{x}$ & $\mathrm{V}$ & $\mathrm{v}$ & $\mathrm{V}$ & $\mathrm{V}$ \\
\hline & Penjualan & $\mathrm{v}$ & V & $\mathrm{v}$ & V & V \\
\hline \multirow[t]{6}{*}{2} & Fungsi Fisik & & & & & \\
\hline & $\begin{array}{l}\text { Pemberian } \\
\text { Pakan }\end{array}$ & $\mathrm{x}$ & $\mathrm{V}$ & $\mathrm{v}$ & $\mathrm{X}$ & $\mathrm{X}$ \\
\hline & Pemeliharaan & $\mathrm{x}$ & $\mathrm{V}$ & $\mathrm{v}$ & $X$ & $X$ \\
\hline & Pengangkutan & $\mathrm{x}$ & $\mathrm{V}$ & $\mathrm{v}$ & $\mathrm{V}$ & $\mathrm{V}$ \\
\hline & Pengolahan & $\mathrm{x}$ & $X$ & $\mathrm{x}$ & $\mathrm{V}$ & $X$ \\
\hline & Penyimpanan & $\mathrm{x}$ & $\mathrm{X}$ & $\mathrm{x}$ & $\mathrm{V}$ & $\mathrm{V}$ \\
\hline \multirow[t]{3}{*}{3} & Fungsi Fasilitas & & & & & \\
\hline & $\begin{array}{l}\text { Penanggungan } \\
\text { Resiko }\end{array}$ & $\mathrm{x}$ & $\mathrm{V}$ & $\mathrm{v}$ & $\mathrm{V}$ & $\mathrm{V}$ \\
\hline & Informasi Pasar & $\mathrm{x}$ & $\mathrm{V}$ & $\mathrm{v}$ & V & $\mathrm{V}$ \\
\hline
\end{tabular}


Fungsi pemasaran peternak adalah penjualan. Peternak menjual sapi kepada tengkulak. Terdapat dua jenis tengkulak yang berperan dalam pemasaran sapi potong, yaitu tengkulak desa dan tengkulak besar. Fungsi pemasaran yang dilakukan oleh tengkulak desa sama dengan tengkulak besar yaitu pembelian, penjualan, pemberian pakan, pemeliharaan, pengangkutan, penanggungan resiko, dan informasi pasar.

Tengkulak melakukan pembelian sapi kemudian untuk dijual kembali. Sebelum sapi berhasil dijual, terlebih dahulu sapi dipelihara selama beberapa hari sehingga membutuhkan pemeliharaan dan pemberian pakan. Tengkulak juga melakukan pengangkutan agar sapi bisa sampai ke lokasi penjualan. Tengkulak akan menanggung resiko selama waktu pemeliharaan dan pada proses pengangkutan. Adapun informasi pasar didapatkan oleh tengkulak dari sesama tengkulak atau dari dinas peternakan.

Fungsi pemasaran RPH yaitu pembelian, penjualan, pengolahan, penanggungan resiko, penyimpanan dan informasi pasar. Rumah Potong Hewan mendapatkan sapi potong melalui perantara tengkulak yang mengantarkan sapi secara langsung. Fungsi fisik pada RPH yaitu pada saat sapi disembelih dan dimanfaatkan dagingnya untuk dijual kembali. Penyimpanan dilakukan oleh RPH sebelum proses pendistribusian agar kualitas daging tetap terjaga. Penanggungan resiko yang dilakukan $\mathrm{RPH}$ jika daging tidak dapat dijual ke pasar dalam waktu singkat sehingga terjadi pembusukan pada daging. Informasi pasar diterima RPH melalui dinas peternakan. Fungsi pemasaran pada saat sapi masuk pasar dan sebelum sampai ke tangan konsumen adalah pembelian, penjualan, pengangkutan, penanggungan resiko, penyimpanan, dan informasi pasar. Pedagang pasar membeli daging sapi dari RPH dengan cara mengambil secara langsung ke RPH kemudian dijual ke konsumen melalui pasar. Informasi pasar yang diterima oleh pedagang pasar berdasarkan harga beli pada RPH. Pedagang pasar akan menanggung resiko selama proses penjualan sapi, dan akan melakukan penyimpanan jika sapi belum habis terjual agar kualitas daging tidak rusak.

\section{KESIMPULAN DAN IMPLIKASI KEBIJAKAN}

\section{Kesimpulan}

Karakteristik peternak di Kecamatan Ciracap terdiri dari $100 \%$ laki - laki, $40 \%$ berumur 40 - 49 tahun, tingkat pendidikan $58 \%$ adalah lulusan $\mathrm{SD}$, jumlah tanggungan keluarga berjumlah $3-5$ orang, dan menjadikan usaha ternak sapi potong sebagai usaha sampingan.

Persepsi peternak terhadap SPR di Kecamatan Ciracap dengan memberikan 30 indikator yaitu : 5 indikator tentang tujuan pengembangan SPR, 9 indikator tentang prinsip pengembangan SPR, 9 indikator tentang pelaksanaan SPR, dan 7 indikator tentang program SPR bernilai rata-rata 194,57. Artinya persepsi peternak terhadap SPR di Kecamatan Ciracap adalah kategori baik. Mayoritas peternak sapi potong menyambut positif dan bersedia menjalankan program SPR sesuai dengan prinsip dan pedoman yang telah disepakati bersama.

Pola pemasaran sapi potong yang saat ini terbentuk adalah dari peternak menjual sapi ke tengkulak yang ada di Kecamatan Ciracap. Kemudian tengkulak tersebut mengantarkan sapinya ke Tempat Pemotongan Hewan (TPH) yang ada di Surade dan Tegal Buleud. Selain itu, jika ada pemesanan sapi potong dari tengkulak yang datang dari Tasikmalaya atau Ciamis, maka tengkulak yang ada di 
Kecamatan Ciracap menyediakan sapi sesuai dengan pemesanan. Sapi potong yang dibeli oleh tengkulak dari Tasikmalaya atau Ciamis selanjutnya akan dibawa ke daerah mereka masing masing untuk pemotongan di Rumah Potong Hewan (RPH) atau untuk dilakukan penggemukan.

\section{Implikasi Kebijakan}

1. Program SPR sapi potong sebaiknya mengayomi secara merata semua peternak yang ada di Kecamatan Ciracap.

2. Pemerintah sebaiknya menambah bantuan kandang agar dapat menampung semua populasi sapi potong agar tercapainya kemudahan dalam satu manajemen dan pengontrolan selama masa pemeliharaan.

3. Peternak sebaiknya bersikap lebih aktif dalam memahami program SPR di Kecamatan Ciracap agar dapat terjalinnya kerjasama yang baik antara peternak dengan pemerintah.

4. Program SPR sebaiknya menjamin saluran tataniaga sapi potong yang baik di Kecamatan Ciracap agar terhindar dari dominasi tengkulak dan terwujudnya keadilan harga bagi peternak.

5. Penggunaan teknologi seperti IB, penanganan penyakit dan teknologi pakan semoga dapat diterapkan dengan baik oleh semua peternak sapi potong yang ada di Kecamatan Ciracap.

6. Semoga SPR sapi potong di Kecamatan Ciracap berhasil mencapai semua tujuannya dengan waktu yang sudah ditentukan, sehingga dapat menjadi percontohan dan semangat baru bagi peternak di daerah lainnya.

7. Semoga program SPR sapi potong dapat terus berlanjut walaupun berganti pemerintahan dan dapat meningkatkan kesejahteraan peternak.

\section{Daftar Pustaka}

Azhari, 1988. "Faktor - Faktor yang Mempengaruhi Adopsi Petani Padi”. Tesis. Program Pasca Sarjana. Institut Pertanian Bogor. Bogor.

Boediyana, Teguh. (2008). "Menyonsong agribisnis persusuan yang prospektif di tanah air". Trobos, No 108 September 2008 Tahun VIII.

Dahl, C.D., Hammond, J. W., 1997. Market Place Analysis The Agryculture Industry. MC. GrawHill Book Company. New York.

Dahl, Dale C and Jerome W. Hammond. 1997. Market and Price Analysis. The Agricultural Industries. McGraw-Hill. USA.

Dinas Peternakan Kabupaten Sukabumi, 2016. Kabupaten Sukabumi dalam Angka. BPS Kabupaten Sukabumi, Sukabumi.

[Dirjennak] Direktorat Jenderal Peternakan, 2010. Statistika Peternakan 2010. Departemen Pertanian, Jakarta.

[Dirjennak] Direktorat Jenderal Peternakan, 2015. Pedoman Umum SPR 2015. Departemen Pertanian, Jakarta.

Dirjen Peternakan dan Kesehatan Hewan, 2015. Pedoman Sentra Peternakan Rakyat (SPR). Jakarta.

Djaali, 2008. Skala Likert. Jakarta: Pustaka Utama.

Gonarsyah, Isang. 1996/1997. Catatan Kuliah Pemasaran Pertanian Lanjutan. Sekolah Pasca Sarjana IPB.

Hidayat, C. 1998. Manajemen Pemasaran. Jakarta : Badan Penerbit IPWI

Holle, Y. 2000. "Partisipasi Petani dalam Kegiatan PIR Kelapa Sawit”. Tesis. 
Program Pasca Sarjana. Institut Pertanian Bogor. Bogor.

Istiyanti, Eni. 2010. Efisiensi Pemasaran Cabai Merah Keriting Di Kecamatan Ngemplak Kabupaten Sleman. Mapeta, 12(2): 116-124.

Kasup, I. 1998. "Kesiapan Peternak dalam Mengembangkan Usaha Peternakan Sapi”. Tesis. Program Pasca Sarjana. Institut Pertanian bogor. Bogor.

Limbong, W.H., dan Panggabean Sitorus., 1985. Pengantar Tataniaga Pertanian. Jurusan Ilmu-Ilmu Sosial Ekonomi Pertanian. Fakultas`Pertanian. Institut Pertanian Bogor. Bogor.

Limbong, W.H., dan Panggabean Sitorus., 1987. Pengantar Tataniaga Pertanian. Jurusan Ilmu-Ilmu Sosial Ekonomi Pertanian. Fakultas`Pertanian. Institut Pertanian Bogor. Bogor.

Maryono, E. Romjali, D.B. Wijono, dan Hartatik. 2006. Paket rakitan teknologi hasil-hasil penelitian peternakan untuk mendukung upaya Kalimantan Selatan mencapai swasembada sapi potong.

Mersyah, R. 2005. Desain sistem budidaya sapi potong berkelanjutan untuk mendukung pelaksanaan otonomi daerah di Kabupaten Bengkulu Selatan. Disertasi, Sekolah Pascasarjana, Institut Pertanian Bogor.

Newcomb, T.M. 1978. Psikologi Sosial. Terjemahan. Diponegoro. Bandung

Nurfitri, E. 2008. Sistem Pemeliharaan dan Produktivitas Sapi Potong pada Berbagai Kelas Kelompok Peternak di Kabupaten Ciamis. Skripsi. Fakultas Peternakan, Institut Pertanian Bogor.
Nurhayati, N, 2011. Terampil Menjadi Peternak, Bandung : Yrama Widya.

Pamuju, 1995. "Komunikasi Bisnis", Jakarta: PT. Gramedia Pustaka Utama.

Pearce dan Robinson. 2011. Manajemen Strategis: Formulasi, Implementasi, dan Pengendalian. Jakarta: Penerbit Salemba Empat.

Pedoman umum penyelenggaraan Sentra Peternakan Rakyat, 2015. Direktorat Jendral Peternakan dan Kesehatan Hewan.

Prahasta, A, 2008. Agribisnis Ternak Sapi, Bandung : Pustaka Grafika.

Rakhmad, J. 2004. Psikologi Komunikasi. Edisi Revisi. Remaja Rosdakarya. Bandung.

Reksowardoyo. 1983. Hubungan beberapa karakteristik warga masyarakat Desa Sarampad, Kabupaten Cianjur dan Persepsi Mereka tentang Ternak Kelinci. Karya Ilmiah. Fakultas Peternakan. Institut Pertanian Bogor. Bogor.

Riady, M. 2004. Tantangan dan peluang peningkatan produksi sapi potong menuju 2020.

Rianto, E 2009. Panduan Lengkan Sapi Potong Penerbit Penebar Swadaya, Jakarta

Setiyono, P.B.W.H.E., Suryahadi, T. Torahmat, dan R. Syarief. 2007. Strategi suplementasi protein ransum sapi potong berbasis jerami dan dedak padi. Jurnal Ilmu Pengetahuan dan Teknologi Peternakan 30(3): 207-217.

Soekartawi, 1988. Prinsip Dasar Komunikasi Pertanian. Universitas Indonesia (UI-Press). Jakarta.

Tomek, William G and Kenneth L. Robinson. 1990. Agricultural Product Prices. Third Edition. Cornell University Press. 